\title{
Boosting the Firm Transformation in Industry 5.0: Experience-Agility Innovation Model
}

\author{
Leonardus W Wasono Mihardjo, Sasmoko, Firdaus Alamsyah, Elidjen
}

\begin{abstract}
Industry 5.0 brings collaborative and automatic environment, thus creating a new paradigm for companies in doing business. The way organizations manage resources and capability, especially in relationship with people, culture and process in creating new business models have changed. Previous studies on developing innovation based on customer experience and agility of organization focus on the concept, relationship among variables and the implication. However, in the context of industry 5.0, the study on those topics has not been revealing. Hence, this study aims to assess the concept of experience-agility innovation model to support transformation in the context of digital transformation to face Industry 5.0. The proposed model was assessed with 195 Indonesia ICT firms using SEM-PLS statistical tools. The findings demonstrate that the firm that offers compelling value proposition from customer experience while concurrently developing agility in the organization to create business model innovation could boost the transformational performance. For further researches, the study can be enhanced through expanding the model, sample, and time.
\end{abstract}

Index Terms: customer experience, organizational agility, business model innovation, transformational performance, industry 5.0

\section{INTRODUCTION}

Industry 4.0 chiefly discusses digitalization focus on adoption of digital technologies such as internet of things, big data, artificial intelligence, blockchain, and cloud computing. Those technologies bring out the capability for adaptive and agile organization to focus on customer experience. While companies are struggling in handling the emerging technologies and agility in Industry 4.0, they need to start to think about the transition into Industry 5.0. Even though both industry 4.0 and 5.0 have kept technology as the centre of their respective businesses, to sustain their business the firms will need to provide agility in organization to involve technology in fulfilling customer aspirations. Industry 5.0 focus on human-centered technology (Fujii, Guo, \& Kamoshida, 2018; Onday, 2019). Industry 5.0 provides smart community and collaboration between people, and smart technology to take over the manual and repetitive tasks integrating with human creativity to elevate

Revised Manuscript Received on September 22, 2019.

Leonardus W Wasono Mihardjo, School of Business, Bina Nusantara University, Jakarta, Indonesia.

Sasmoko, Primary Teacher Education Departmeny, Bina Nusantara University, Jakarta, Indonesia. Email: sasmoko@binus.edu

Firdaus Alamsyah, School of Business, Bina Nusantara University, Jakarta, Indonesia.

Elidjen, School of Business, Bina Nusantara University, Jakarta, Indonesia the quality of product and service in creating customer experience. The combination of quality service, customer experience and organizational agility provides a balance between economic advancement with social resolution (Paschek, Mocan, \& Draghici, 2019)

The changing of the societal paradigm brings the challenge of the company to survive and sustain their business to face Society 5.0. The previous studies have shown that the linking customer experience with mapping of business model has enabled companies to create innovation to survive in a disruptive era (Loss \& Crave, 2011; Leonardus W Wasono Mihardjo, Sasmoko, Alamsjah, \& Elidjen, 2019). Thus, customer experience becomes a source of competitive advantage when the linkage between customer experience and business model could be synergized (Seppanen \& Laukkanen, 2015). Business models have been intensively discussed and well suited to depicting current business and become the practical tools to visualize value proposition (Chesbrough \& Rosenbloom, 2002; Osterwalder \& Pigneur, 2010; Teece \& Linden, 2017; Zott \& Amit, 2017). Business models are also linked to the concepts of value creation for collaboration as part of value co-creation (Basceanu, 2014; Nenonen \& Storbacka, 2010). Putting more customers in collaboration could create more customer experience as the central element of a promise of values created for the customers by a firm's offering (Ramaswamy, 2008; Sjödin \& Kristensson, 2012). To support the development of business model and customer experience in a differentiated value proposition of the firm, the firm is required to transform their static capability into most important dimension of organization in term of agility organization as the source of sustainable value creation (Carvalho, Sampaio, Rebentisch, Carvalho, \& Saraiva, 2017). The agility of an organization is determined by human factor related with people, culture and process (Carvalho et al., 2017; Crocitto \& Youssef, 2003). Since Industry 5.0 also puts the attention on human centre supported by technology in developing a smart community, the agility of the organization takes a crucial part for the firms.

However, there is scant evidence on how a firm could construct business model innovation and put human centre as a cultural mindset that enables the firm to generate new business opportunities, especially in anticipating the new Society 5.0 . 
The human centre puts into the way of the firms to look at the opportunity based on the feedback from customer experience and the way of organization to adapt to change and perform business model become a crucial part to facing industry 5.0. Hence, in this paper, in anticipating Industry 5.0 , the study put a central element of customer experience and agility organizational that focus on human centre to develop business model innovation to improve transformational performance.

The structure of the paper is as follows: First, we discuss recent perspectives on experience-agility and business model innovation as well as the hypothesis development. Then we discuss the research model, methodology, research findings, discussion and the implication model with an experience-agility innovation model for implication to theory and practice before conclusions and suggestions for further research.

\section{LITERATURE REVIEW}

\section{A. Industry 5.0 and transformational Performance}

Industry 5.0 brings the new paradigm of the way the firm to manage the company. The use of Internet of things (IoT) enables the collaboration shift from individual collaboration to society collaboration, enabling advanced services through interconnecting and evolving interoperable information and communication technologies (Zhang et al., 2015). This interconnection and interoperability have impacted on releasing any constrain due to the nature of internet and digital technology to boost development of smart society (Onday, 2019). The Industry 5.0 also brings the positive impact by resolving social issues and creating abundance for society since the knowledge society are being identified and integrated into online society supported by technology (Wang, Yuan, Wang, \& Qin, 2018). The concept of measurement to ensure the transformation program on the track shall consider the long-term objective to support sustainable development as shown in Figure 1.

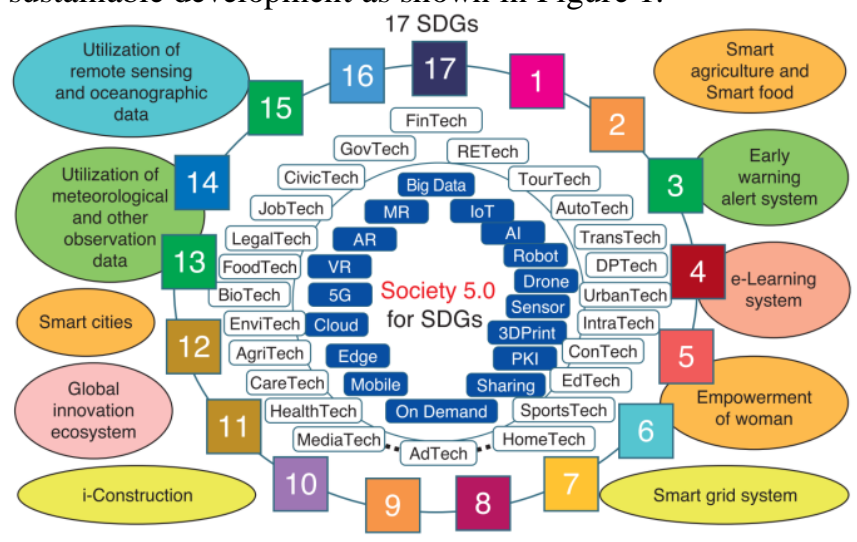

Figure 1. Sustainable development in society 5.0 (Mayumi Fukuyama, 2018)

The performance measurement in transformational performance shall consider not only existing performance but also sustainable development element in society 5.0 which are the potential performance coming from the technology and the ecosystem related with society development. Hence, to address the transformation of the firm, this study uses the dimension of transformational performance.

\section{B. Customer Experience}

Industry 5.0 focuses on human centre, while customer experience mostly related with human experience that related with sensory behavior, cognitive and social of customers as humans (Bolton, 2016; Ramaswamy, 2011). Customer experience involves every chain of customer's journey as part of a company's offering (Lemon \& Verhoef, 2016). Hence, the scope of customer experience covers the journey of customer, starting from relation, engagement in service or product, usage and after product and service engagements including loyalty and brand performance (Palmer, 2010; Priyanka Shrivastava, 2016). In digital era, customer experience becomes a critical part of the success of the company, since the digital technology could provide new interactions with customers and enable customers to have direct influence on the company (Leonardus W Wasono Mihardjo et al., 2019; Parise, Guinan, \& Kafka, 2016).

In industry 5.0, the experience of customers has shifted from personalization of customization into mass customization based on society development (Bansal, 2018) through development technological platforms to expand in scale maximum product customization with flexibility to the customer. The use of technology is critical to obtain the right information and major important as the feedback to the firm in decision making (Meyer \& Schwager, 2007). Hence, the use of big data to support development of the journey of customer in society 5.0 has significant influence to drive economic and social value (Chandola, 2015; Özdemir \& Hekim, 2018). With technology capability, the point out of experiences could provide distinct firm capability.

Overall customer experience could lead to customer satisfaction (Brochado, Troilo, \& Shah, 2017; Fatma, 2014) and sustainability (Chandola, 2015) which an antecedent of brand performance, customer relation, price and promotion as well as service offering in personalization. Furthermore, in society community, the experience of customer can be the opportunity to create a new promoter (Situmorang, Rini, \& Muda, 2017). Although some potential pitfalls can happen as a tradeoff, that a superior experience may be quite expensive (Lemon \& Verhoef, 2016).

\section{Organizational Agility}

Since industry 5.0 focuses on collaboration among machines and humans, with humans as the centre of creativity. Therefore, the organizational agility in industry 5.0 was focused on humans as the centre for agility. The organizational agility could be defined as the adaptability of the firm to adjust strategic direction to align with the core business to create value (Doz \& Kosonen, 2010).

Published By: 

terms of simplification and fast-moving decision (Hugos, 2009). Agility is the ability to adapt with the market change with high quality service, low cost with shorter time in varying product volume to create customer value (Vokurka \& Fliedner, 1998). In this study we refer the organizational agility is the firm's capability to adapt to changes by providing effective and efficient capacity to create value.

In addition, to face society 5.0, the organizational agility merely focuses on resource deployment to be more effective and efficient. The best approach may be to build the organization based on the human factors: people, culture and process (Carvalho et al., 2017; Crocitto \& Youssef, 2003). People is centre of the firm's capability to take opportunity and risk to create company value. The culture and process could bring the company more profitable by optimizing operations and achieve efficiency as part of culture and the lean process of the organization (Banu Ozkeser, 2018). Understanding the organizational agility based on human as centre requires an overall framework of sustainable foundation of the firm to make higher-quality decisions and to help scholars to have a better understanding in facing Society 5.0.

\section{Business model innovation}

Society 5.0 enables the collaboration between machine and humans through technology; it means a new business model where building a cooperative relation between machine and human has become a critical part. Business model is defined as a rationale organization to perform value delivery by providing systematic tool through business model canvas (Osterwalder \& Pigneur, 2010). Business model innovation as a process enables other network to contribute and innovate in delivering value (Berglund \& Sandström, 2013; Chesbrough, 2012). The last study demonstrates that the majority of business executives believe that new business models innovation has a greater source of competitive advantage than new products and services (Bashir \& Verma, 2017). The term of business model innovation was extended to the effort to create value for sustainability (Inigo, Albareda, \& Ritala, 2017). However, the grand challenge remains: current business model innovation fails to sufficiently consider the sustainability dimension (Boons \& Lüdeke-Freund, 2013), The result of business model innovation could make a firm lost opportunity for embedding sustainability in terms of content, structure and governance dimensions that the firm capability could not perform well (Zott \& Amit, 2010) to anticipate the development of society 5.0 in the future. hence the sustainability dimension for business model innovation based on content, structure and governance innovation being explored in this study.

\section{Hypothesis Development}

The previous study has found that customer experience has relation in developing of business model innovation where customer experience as a centre of building business model innovation (Seppanen \& Laukkanen, 2015). The relationship between business model innovation and customer experience was also involving the collaboration between customer and
Agility can also be defined as part of making flexibility in

firms (Loss \& Crave, 2011) and customer experience has played a significant role in developing firm performance (Fatma, 2014; Stuart \& Tax, 2004). Hence, we develop the hypothesis as follow:

Hypothesis 1: Customer Experience has significant effects on Business Model Innovation

Hypothesis 2: Customer Experience has significant effects on Transformational performance

The relationship between organization and business model innovation has been discussed to perform agile business model innovation (Loss \& Crave, 2011). And model agility driven business model could perform the performance (Arbussa, Bikfalvi, \& Marquès, 2017). Hence, the hypothesis can be formulated as follows:

Hypothesis 3: Organizational Agility has significant effects on Business Model innovation

Hypothesis 4: Organizational Agility has significant effects on Transformational Performance

Many studies have found that business model innovation has significant influence to drive firm's performance (Amit \& Zott, 2010; Cucculelli \& Bettinelli, 2015; Leonardus Wahyu Wasono Mihardjo, Alamsjah, Elidjen, \& Sasmoko, 2018) The hypothesis then can be concluded as follows:

Hypothesis 5: BMI has significant effects to

Transformational Performance

According to those previous study, the development of research model can be performed in Figure 2.

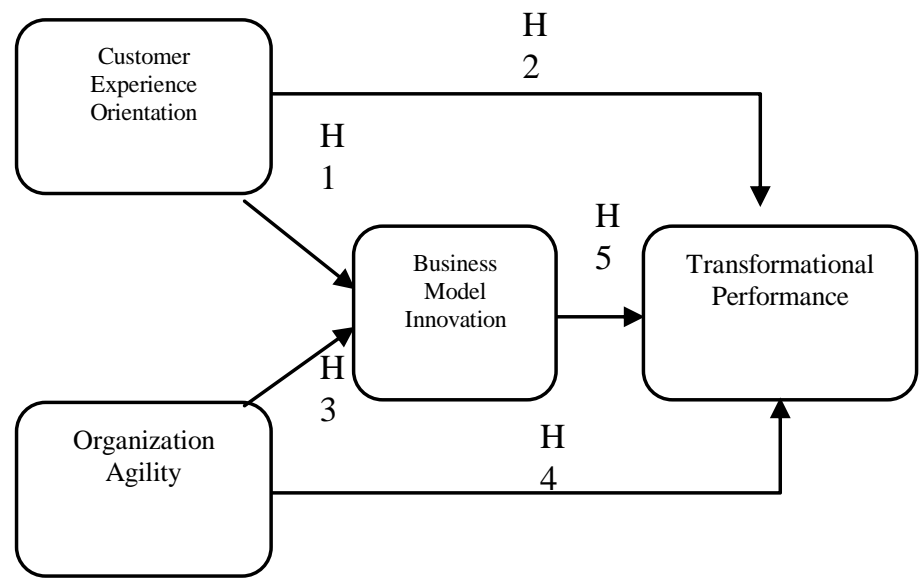

Figure 2. The Research Model

\section{Method}

The survey-based study used questionnaires to collect primary data to assess the model of experience-agility innovation model by focusing on the ICT companies of Indonesia. Data were collected from senior leaders as the representative of these company. In general, the determination of study sample size is a balance between resource capability and adequate statistical requirement. According to, simple rule of thumb suggested that a sample that is larger than 30 and less than 500 (Cohen, 1992). 


\section{Boosting the Firm Transformation in Industry 5.0: Experience-Agility Innovation Model}

According to Pallant (2013) the most suitable sample has to 5 times of indicators. Hence, this study provides the sample with numbers of 195 samples out of population of 542 (ministry of communication and information, 2017) which is higher than minimum of 190 samples as result 5 times 38 of indicators. Thus, 225 questionnaires were distributed among the employees of ICT companies in Indonesia. All the questionnaires were distributed by using random sampling techniques. In total, 201 answers were received, and 195 valid responses were used to analyze the data. Partial Least Square (PLS) is used for statistical tool in data analysis.

\section{Result}

Figure 3 shows the first step of PLS-SEM in which measurement model. In the next step, it is found that the factor loading is above 0.5 which confirms the internal consistency. Composite reliability (CR) and average variance extracted (AVE) is also higher than 0.7 and 0.5 respectively. All the results are demonstrated in Table 1.

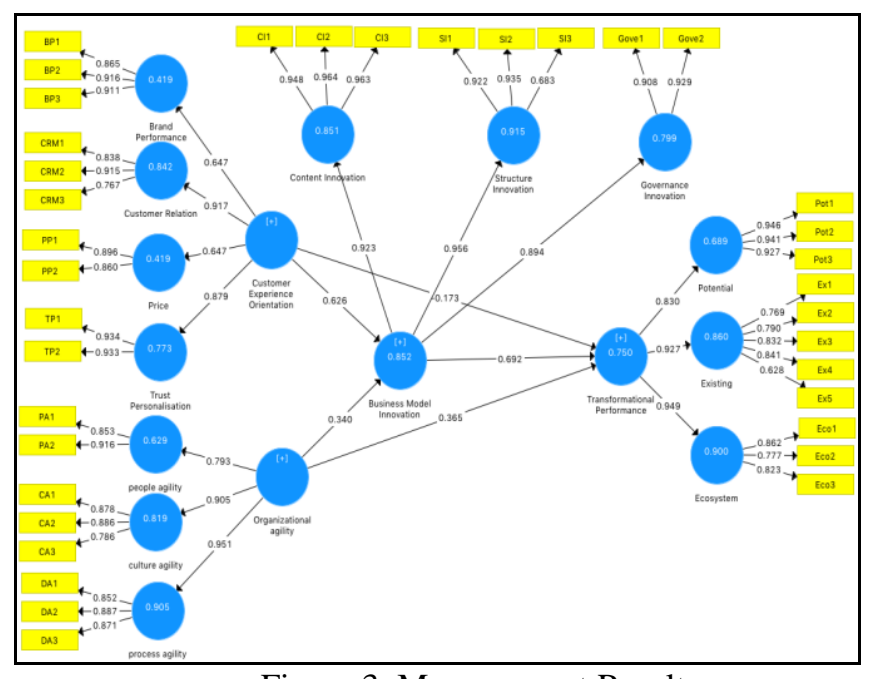

Figure 3. Measurement Result

Table 1. Construct's Reliability and Validity

\begin{tabular}{|l|r|r|c|c|}
\hline & $\begin{array}{c}\text { Cronbach's } \\
\text { Alpha }\end{array}$ & rho_A & $\begin{array}{c}\text { Compo } \\
\text { site } \\
\text { Reliabil } \\
\text { ity }\end{array}$ & AVE \\
\hline Business Model Innovation & 0.897 & 0.911 & 0.923 & 0.670 \\
\hline Customer Experience Orientation & 0.923 & 0.934 & 0.936 & 0.576 \\
\hline Organizational agility & 0.938 & 0.942 & 0.947 & 0.621 \\
\hline Transformational Performance & 0.896 & 0.899 & 0.919 & 0.619 \\
\hline
\end{tabular}

Discriminant validity is given in Table 2. This study used cross loadings method for this purpose.

Table 2. Cross Loading

\begin{tabular}{|c|c|c|c|c|c|c|c|c|c|c|c|c|c|}
\hline & $\begin{array}{c}\text { Brand } \\
\text { Perf }\end{array}$ & $\begin{array}{l}\text { Conten } \\
\mathrm{t} \text { Innov } \\
\end{array}$ & $\begin{array}{l}\text { Cust } \\
\text { Rel. }\end{array}$ & Ecosystem & Existing & $\begin{array}{c}\text { Gov } \\
\text { Innov }\end{array}$ & $\begin{array}{c}\text { Potentia } \\
1\end{array}$ & Price & $\begin{array}{c}\text { Structure } \\
\text { Innov }\end{array}$ & $\begin{array}{c}\text { Trust } \\
\text { Persona } \\
1 \\
\end{array}$ & $\begin{array}{c}\text { Cultur } \\
\text { e } \\
\text { Agility } \\
\end{array}$ & $\begin{array}{c}\text { People } \\
\text { agility }\end{array}$ & $\begin{array}{c}\text { Proces } \\
s \\
\text { agility } \\
\end{array}$ \\
\hline BP1 & 0.865 & 0.171 & 0.3 & 0.049 & 0.427 & 0.443 & 0.316 & 0.545 & 0.165 & 0.215 & 0.349 & 0.054 & 0.305 \\
\hline BP2 & 0.916 & 0.293 & 0.601 & 0.248 & 0.609 & 0.647 & 0.505 & 0.383 & 0.442 & 0.369 & 0.609 & 0.312 & 0.588 \\
\hline BP3 & 0.911 & 0.315 & 0.489 & 0.165 & 0.561 & 0.535 & 0.441 & 0.411 & 0.396 & 0.38 & 0.524 & 0.189 & 0.433 \\
\hline $\mathrm{CA} 1$ & 0.357 & 0.442 & 0.507 & 0.484 & 0.492 & 0.427 & 0.629 & 0.297 & 0.53 & 0.365 & 0.878 & 0.62 & 0.758 \\
\hline $\mathrm{CA} 2$ & 0.491 & 0.229 & 0.394 & 0.278 & 0.423 & 0.337 & 0.491 & 0.182 & 0.396 & 0.255 & 0.886 & 0.38 & 0.707 \\
\hline $\mathrm{CA} 3$ & 0.592 & 0.575 & 0.576 & 0.535 & 0.688 & 0.74 & 0.789 & 0.478 & 0.675 & 0.463 & 0.786 & 0.517 & 0.799 \\
\hline CI1 & 0.118 & 0.948 & 0.62 & 0.569 & 0.512 & 0.604 & 0.529 & 0.559 & 0.75 & 0.753 & 0.425 & 0.519 & 0.497 \\
\hline $\mathrm{CI} 2$ & 0.331 & 0.964 & 0.688 & 0.668 & 0.675 & 0.776 & 0.591 & 0.606 & 0.855 & 0.824 & 0.471 & 0.476 & 0.541 \\
\hline $\mathrm{CI} 3$ & 0.396 & 0.963 & 0.732 & 0.666 & 0.707 & 0.784 & 0.694 & 0.628 & 0.857 & 0.813 & 0.546 & 0.572 & 0.62 \\
\hline CRM1 & 0.418 & 0.603 & 0.838 & 0.392 & 0.484 & 0.519 & 0.667 & 0.356 & 0.648 & 0.526 & 0.569 & 0.616 & 0.648 \\
\hline CRM2 & 0.273 & 0.681 & 0.915 & 0.444 & 0.422 & 0.444 & 0.582 & 0.351 & 0.735 & 0.735 & 0.47 & 0.609 & 0.577 \\
\hline CRM3 & 0.667 & 0.508 & 0.767 & 0.448 & 0.677 & 0.609 & 0.455 & 0.52 & 0.562 & 0.672 & 0.451 & 0.428 & 0.438 \\
\hline DA1 & 0.316 & 0.372 & 0.485 & 0.517 & 0.487 & 0.469 & 0.712 & 0.021 & 0.558 & 0.242 & 0.717 & 0.592 & 0.852 \\
\hline DA2 & 0.404 & 0.685 & 0.63 & 0.524 & 0.545 & 0.681 & 0.737 & 0.397 & 0.739 & 0.521 & 0.771 & 0.632 & 0.887 \\
\hline DA3 & 0.604 & 0.438 & 0.592 & 0.477 & 0.658 & 0.592 & 0.797 & 0.407 & 0.634 & 0.431 & 0.844 & 0.56 & 0.871 \\
\hline Eco1 & 0.126 & 0.403 & 0.245 & 0.862 & 0.706 & 0.517 & 0.619 & 0.316 & 0.467 & 0.283 & 0.424 & 0.482 & 0.491 \\
\hline $\mathrm{Eco} 2$ & 0.27 & 0.743 & 0.677 & 0.777 & 0.713 & 0.646 & 0.685 & 0.319 & 0.781 & 0.753 & 0.584 & 0.618 & 0.637 \\
\hline$E \operatorname{co} 3$ & 0.061 & 0.5 & 0.346 & 0.823 & 0.624 & 0.466 & 0.37 & 0.34 & 0.503 & 0.382 & 0.267 & 0.426 & 0.292 \\
\hline Ex1 & 0.528 & 0.662 & 0.561 & 0.611 & 0.769 & 0.789 & 0.598 & 0.534 & 0.689 & 0.572 & 0.514 & 0.438 & 0.493 \\
\hline Ex2 & 0.295 & 0.543 & 0.417 & 0.778 & 0.79 & 0.623 & 0.587 & 0.453 & 0.511 & 0.488 & 0.454 & & 0.461 \\
\hline
\end{tabular}


International Journal of Recent Technology and Engineering (IJRTE) ISSN: 2277-3878, Volume-8 Issue-2S9, September 2019

\begin{tabular}{|c|c|c|c|c|c|c|c|c|c|c|c|c|c|}
\hline Ex3 & 0.34 & 0.555 & 0.479 & 0.767 & 0.832 & 0.629 & 0.688 & 0.343 & 0.638 & 0.418 & 0.52 & 0.503 & 0.645 \\
\hline Ex4 & 0.734 & 0.443 & 0.634 & 0.56 & 0.841 & 0.745 & 0.693 & 0.382 & 0.595 & 0.424 & 0.542 & 0.517 & 0.551 \\
\hline Ex5 & 0.617 & 0.299 & 0.335 & 0.394 & 0.628 & 0.506 & 0.308 & 0.4 & 0.347 & 0.395 & 0.49 & 0.191 & 0.3 \\
\hline Gove1 & 0.71 & 0.581 & 0.52 & 0.522 & 0.78 & 0.908 & 0.729 & 0.595 & 0.653 & 0.48 & 0.584 & 0.356 & 0.606 \\
\hline Gove2 & 0.44 & 0.796 & 0.618 & 0.684 & 0.781 & 0.929 & 0.676 & 0.459 & 0.733 & 0.623 & 0.533 & 0.611 & 0.628 \\
\hline PA1 & 0.252 & 0.44 & 0.478 & 0.582 & 0.511 & 0.45 & 0.394 & 0.27 & 0.434 & 0.362 & 0.468 & 0.853 & 0.465 \\
\hline PA2 & 0.16 & 0.518 & 0.661 & 0.528 & 0.458 & 0.495 & 0.726 & 0.143 & 0.638 & 0.356 & 0.59 & 0.916 & 0.717 \\
\hline PP1 & 0.352 & 0.62 & 0.46 & 0.449 & 0.527 & 0.505 & 0.352 & 0.896 & 0.445 & 0.634 & 0.403 & 0.315 & 0.317 \\
\hline PP2 & 0.505 & 0.469 & 0.393 & 0.23 & 0.409 & 0.494 & 0.264 & 0.86 & 0.302 & 0.508 & 0.27 & 0.059 & 0.252 \\
\hline Pot1 & 0.37 & 0.639 & 0.636 & 0.625 & 0.658 & 0.682 & 0.946 & 0.372 & 0.76 & 0.446 & 0.729 & 0.689 & 0.826 \\
\hline Pot2 & 0.482 & 0.545 & 0.644 & 0.651 & 0.721 & 0.688 & 0.941 & 0.286 & 0.723 & 0.452 & 0.725 & 0.55 & 0.808 \\
\hline Pot3 & 0.502 & 0.598 & 0.614 & 0.652 & 0.771 & 0.776 & 0.927 & 0.337 & 0.806 & 0.474 & 0.69 & 0.603 & 0.788 \\
\hline SI1 & 0.39 & 0.779 & 0.729 & 0.703 & 0.75 & 0.776 & 0.849 & 0.374 & 0.922 & 0.629 & 0.598 & 0.703 & 0.759 \\
\hline SI2 & 0.345 & 0.834 & 0.735 & 0.584 & 0.634 & 0.695 & 0.718 & 0.358 & 0.935 & 0.721 & 0.521 & 0.509 & 0.626 \\
\hline SI3 & 0.264 & 0.56 & 0.484 & 0.524 & 0.457 & 0.418 & 0.472 & 0.394 & 0.683 & 0.442 & 0.54 & 0.325 & 0.5 \\
\hline SI4 & 0.264 & 0.56 & 0.484 & 0.524 & 0.457 & 0.418 & 0.472 & 0.394 & 0.683 & 0.442 & 0.54 & 0.325 & 0.5 \\
\hline TP1 & 0.381 & 0.763 & 0.721 & 0.483 & 0.565 & 0.588 & 0.472 & 0.645 & 0.62 & 0.934 & 0.378 & 0.384 & 0.432 \\
\hline TP2 & 0.311 & 0.792 & 0.719 & 0.585 & 0.538 & 0.542 & 0.439 & 0.577 & 0.708 & 0.933 & 0.433 & 0.369 & 0.434 \\
\hline
\end{tabular}

Structural model is highlighted in Figure 3 which is examined to test the relationship between variables. In this process, hypotheses were examined to check whether the hypotheses are supported or not. T-value was considered to test the hypotheses. The hypotheses having t-value above 1.96 were accepted and hypotheses having t-value below 1.96 were not supported. These results are available in Table 4. It is found that customer experience orientation has no significant impact on driving business model innovation, which supported $\mathrm{H}_{1}$. The relationship between customer experience orientation was positive impact to boost transformational performance, which supported $\mathrm{H}_{2}$. In the same direction, the effect of organizational agility has significant impact on business model innovation and transformational performance, which supported $\mathrm{H}_{3}$ and $\mathrm{H}_{4}$, respectively. Business model innovation has positive effect on transformational performance which supported $\mathrm{H}_{5}$

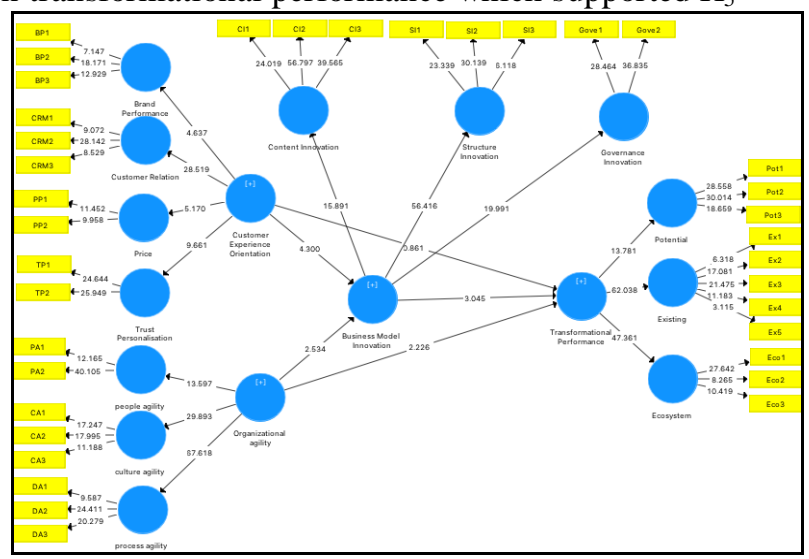

Figure 3. Structural Model Result

The result of hypothesis testing as follows:

Table 4. Testing of Hypothesis partially

\begin{tabular}{|c|l|c|c|c|c|}
\hline & Hypothesis & $\begin{array}{c}\text { Standard } \\
\text { Deviation }\end{array}$ & $\begin{array}{c}\text { T } \\
\text { Statistics }\end{array}$ & $\begin{array}{c}\mathbf{P} \\
\text { Values }\end{array}$ & Remarks \\
\hline 1 & $\begin{array}{l}\text { Customer } \\
\text { Experience } \\
\text { Orientation -> } \\
\text { Business Model } \\
\text { Innovation }\end{array}$ & 0.146 & 4.300 & 0.000 & $\begin{array}{c}\text { Significan } \\
\mathrm{t}\end{array}$ \\
\hline 2 & $\begin{array}{l}\text { Customer } \\
\text { Experience } \\
\text { Orientation -> } \\
\text { Transformational } \\
\text { Performance }\end{array}$ & 0.202 & 0.861 & 0.389 & $\begin{array}{c}\text { Significan } \\
\mathrm{t}\end{array}$ \\
\hline 3 & $\begin{array}{l}\text { Organizational } \\
\text { agility -> Business } \\
\text { Model Innovation }\end{array}$ & 0.134 & 2.534 & 0.011 & $\begin{array}{c}\text { Significan } \\
\mathrm{t}\end{array}$ \\
\hline 4 & $\begin{array}{l}\text { Organizational } \\
\text { agility -> } \\
\text { Transformational } \\
\text { Performance }\end{array}$ & 0.164 & 2.226 & 0.026 & $\begin{array}{c}\text { Significan } \\
\mathrm{t}\end{array}$ \\
\hline 5 & $\begin{array}{l}\text { Business Model } \\
\text { Innovation -> } \\
\text { Transformational } \\
\text { Performance }\end{array}$ & 0.227 & 3.045 & 0.002 & $\begin{array}{c}\text { Significan } \\
\mathrm{t}\end{array}$ \\
\hline
\end{tabular}

* significant at $\langle=0.05$ ( $\mathrm{T}$ statistics $>1.96)$

The Indirect hypothesis test to measure the simultaneous hypothesis test to assess the intervening role of dependent variables. Table 5 demonstrates business model innovation plays a significant role on the relationship between customer experience orientation and transformational performance as well as the relationship between organizational agility and transformational performance. 
Table 5. Testing of Hypothesis simultaneous

\begin{tabular}{|l|r|r|r|l|}
\hline \multicolumn{1}{|c|}{ Hypothesis } & $\begin{array}{r}\text { Standard } \\
\text { Deviation }\end{array}$ & $\begin{array}{c}\text { T } \\
\text { Statisti } \\
\text { cs }\end{array}$ & P Values & Remarks \\
\hline $\begin{array}{l}\text { Customer Experience Orientation - } \\
>\text { Business Model Innovation -> } \\
\text { Transformational Performance }\end{array}$ & 0.168 & 2.581 & 0.010 & Significant \\
\hline $\begin{array}{l}\text { Organizational agility -> Business } \\
\text { Model Innovation -> } \\
\text { Transformational Performance }\end{array}$ & 0.121 & 1.974 & 0.049 & Significant \\
\hline
\end{tabular}

* significant at $\langle=0.05$ (T statistics $>1.96)$

\section{DISCUSSION}

The finding demonstrates that business model innovation plays significant role to boost transformational performance to anticipate Society 5.0. This quantitative research reveals that the human centre supported by technology will drive the transformational performance. It is shown from the finding that organizational agility based on human capability has higher significant influence compared to customer experience orientation. This finding also reveals issues related the firm transformation to face society 5.0: challenges in improving people competence, culture of innovation and the process related to the use of technology (Paschek et al., 2019). Customer experience in industry 5.0's focus on mass customize based platform collaboration is also revealed in this study. The customer relation plays significant influence in developing customer experience, because with multichannel relations customer could access any firm service to perform collaborative innovation. Figure 4 shown the transformation model for the firm in facing industry 5.0 based on experience-agility innovation model. The transformational performance that focuses on existing performance, potential performance and ecosystem performance could be managed when the company could control the revenue, maintenance, development and cost as the continuous innovation. The enabler to achieve the implementation system is supported by business model innovation that consists of content, structure and governance innovation to support revenue as well as customer experience in managing maintenance, development and costs. Customer relation is a critical part in creating customer experience. The foundation of the transformation firm in society 5.0 is people, process and culture supported by technology to achieve effective and efficient value creation.

The model of experience-agility innovation provides implications of the manager of the firm in providing fast decision making in all company process to support the effective and efficient value creation.

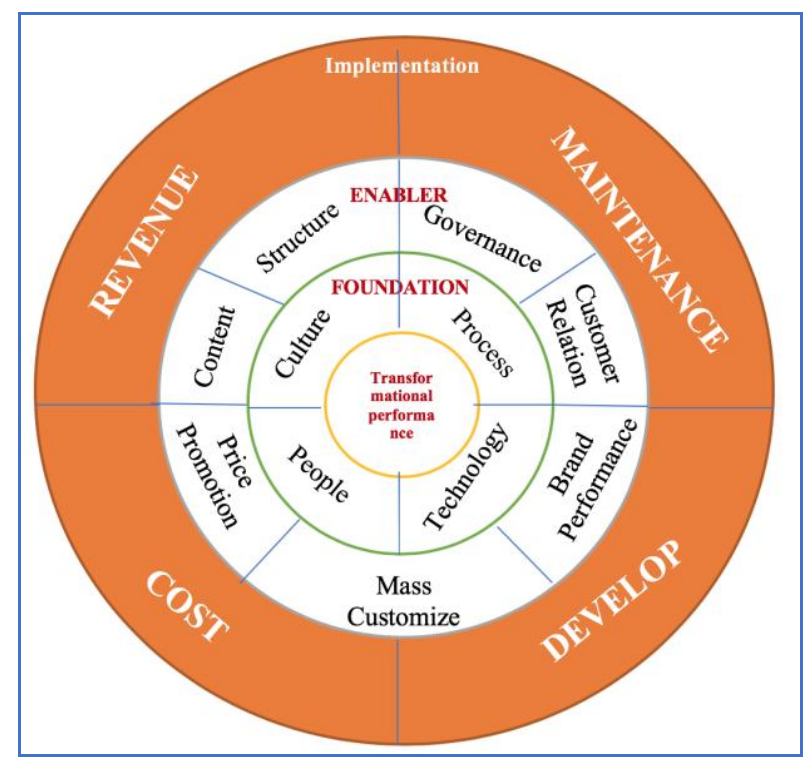

Figure 4. Experience-Agility Innovation Model

The model also contributed to the theory of sustainability for transforming the firm in anticipating the changing of society as impact of massive technology developments.

\section{CONCLUSIONS}

This paper demonstrates the new model of transformation, that focus on exploiting the customer experience and organizational agility concept. Customer experience and organizational agility can be the source of competitive advantage in industry 5.0 The proposed model of experience-agility innovation can be used in many perspectives, which is helpful in the business model innovation process, enhancing revenue, and increasing profit and loss. Although the model can reveal some indicators of society 5.0, the fact the sample and the time of survey are limited, thus further studies are needed. Further research is needed to develop customer experience and customer experience scales that can be utilized effectively in business model design by expanding the sample across industry and country and expanding the time of study to come up with longitudinal study. Finally, it could be an interesting research topic, when the study could reveal possible contradictions between the different customer experience requirements of a company's different business model

\section{Acknowledgement}

The author acknowledges the work of Telkom University, the assistance of Bengris Pasaribu and team as well as Telin Management, for their assistance and collaboration in contributing to data collection and provide feedback design of application for Kartu As2in1 


\section{REFERENCES}

1. Amit, R., \& Zott, C. (2010). Business Model Innovation: Creating Value in Times of Change. Universia Business Review (Vol. 3). https://doi.org/10.2139/ssrn.1701660

2. Arbussa, A., Bikfalvi, A., \& Marquès, P. (2017). Strategic agility-driven business model renewal: the case of an SME. Management Decision, 55(2), 271-293. https://doi.org/10.1108/MD-05-2016-0355

3. Bansal, S. (2018). Industry 5. 0 - Next Generation Customer Experience Redefined? Retrieved from https://www.thedigitaltransformationpeople.com/channels/customerengagement/industry-5-0-next-generation-customer-experience-redefine d/

4. Banu Ozkeser. (2018). Lean Innovation Approach in Industry 5.0. In the Eurasia Proceedings of Science (Vol. 2, pp. 422-428). Retrieved from www.isres.org

5. Basceanu, L. (2014). Business Model Innovation and Value Co-Creation - based on a single case study on Liz Claiborne Retrieved

from http://studenttheses.cbs.dk/bitstream/handle/10417/4570/lelia_ecaterina basceanupdf.pdf? sequence $=1$

6. Bashir, M., \& Verma, R. (2017). Why Business Model Innovation Is the New Competitive Advantage. The IUP Journal of Business Strategy, XIV(1), 7-18. Retrieved from https://search.proquest.com/docview/1891339723/fulltextPDF/ED6D5 CF800FE42FBPQ/1 ?accountid $=8155$

7. Berglund, H., \& Sandström, C. (2013). Business model innovation from an open systems perspective: structural challenges and managerial solutions. International Journal of Product Development, 18(3/4), 274. https://doi.org/10.1504/IJPD.2013.055011

8. Bolton, R. N. (2016). Service excellence: Creating customer experiences that build relationships. (N. Maholtra, Ed.). New York: Business Expert Press, LLC. Retrieved from http://www.ruthnbolton.com/Webinar160915_Bolton.pdf

9. Boons, F., \& Lüdeke-Freund, F. (2013). Business models for sustainable innovation: State-of-the-art and steps towards a research agenda. Journal of Cleaner Production, 45, 9-19. https://doi.org/10.1016/j.jclepro.2012.07.007

10. Brochado, A., Troilo, M., \& Shah, A. (2017). Airbnb customer experience: Evidence of convergence across three countries. Annals of Tourism Research, 63(2017), 210-212. https://doi.org/10.1016/j.annals.2017.01.001

11. Carvalho, A. M., Sampaio, P., Rebentisch, E., Carvalho, J. Á., \& Saraiva, P. (2017). Operational excellence, organisational culture and agility: the missing link? Total Quality Management and Business Excellence, 4(2017), 1-20. https://doi.org/10.1080/14783363.2017.1374833

12. Chandola, V. (2015). Digital Transformation and Sustainability Study and Analysis. Cambridge, Massachusetts.

13. Chesbrough, H. (2012). Open Innovation: Where We've Been and Where We're Going. Research-Technology Management, 55(4), 20-27. https://doi.org/10.5437/08956308X5504085

14. Chesbrough, H., \& Rosenbloom, R. S. (2002). The role of the business model in capturing value from innovation: evidence from Xerox Corporation' s technology spin-off companies. Industrial and Corporate Change, 11(3), 529-555. https://doi.org/10.1093/icc/11.3.529

15. Cohen, J. (1992). Quantitative Methods in psychology: A Power Primer. $\begin{array}{lll}\text { Psychological Bulletin, } & 112(1), & 155-159\end{array}$ https://doi.org/10.1016/j.jorganchem.2011.01.025

16. Crocitto, M., \& Youssef, M. (2003). The human side of organizational agility. Industrial Management and Data Systems, 103(6), 388-397. https://doi.org/10.1108/02635570310479963

17. Cucculelli, M., \& Bettinelli, C. (2015). Business models, intangibles and firm performance: evidence on corporate entrepreneurship from Italian manufacturing SMEs. Small Business Economics, 45(2), 329-350. https://doi.org/10.1007/s11187-015-9631-7

18. Doz, Y. L., \& Kosonen, M. (2010). Embedding Strategic Agility A Leadership Agenda for Accelerating Business Model Renewal. Long Range Planning, 43(2010), 370-382. https://doi.org/10.1016/j.lrp.2009.07.006

19. Fatma, S. (2014). Antecedents and Consequences of Customer Experience Management- A Literature Review and Research Agenda. International Journal of Business and Commerce, 3(6), 32-49.

20. Fujii, T., Guo, T., \& Kamoshida, A. (2018). A Consideration of Service Strategy of Japanese Electric Manufacturers to Realize Super Smart Society (SOCIETY 5.0). In Knowlege Management in Organization (pp. 634-645). Switzerland: Springer International Publishing. https://doi.org/10.1109/ICAICT.2011.6110900

21. Hugos, M. H. (2009). business agility: sustainable prosperity in relentlessly competitive world (1st ed.). New Jersey: John Wiley \& Sons, Inc.
22. Inigo, E. A., Albareda, L., \& Ritala, P. (2017). Business model innovation for sustainability: exploring evolutionary and radical approaches through dynamic capabilities. Industry and Innovation, 24(5), 515-542. https://doi.org/10.1080/13662716.2017.1310034

23. Lemon, K. N., \& Verhoef, P. C. (2016). Understanding Customer Experience Throughout the Customer Journey. Journal of Marketing, 80(6), 69-96. https://doi.org/10.1509/jm.15.0420

24. Loss, L., \& Crave, S. (2011). Agile Business Models: An approach to support collaborative networks. Production Planning and Control, 22(5-6), 571-580. https://doi.org/10.1080/09537287.2010.536646

25. Mayumi Fukuyama. (2018). Society 5.0: Aiming for a New Human-centered Society. Japan SPOTLIGHT, 27(July / August 2018), $8-13$.

26. Meyer, C., \& Schwager, A. A. (2007). Understanding customer experience. Harvard Business Review. https://doi.org/10.1108/00242539410067746

27. Mihardjo, Leonardus W Wasono, Sasmoko, Alamsjah, F., \& Elidjen, E. (2019). The influence of digital customer experience and electronic word of mouth on brand image and supply chain sustainable performance. Uncertain Supply Chain Management, 7(2019), 691-702. https://doi.org/10.5267/j.uscm.2019.4.001

28. Mihardjo, Leonardus Wahyu Wasono, Alamsjah, F., Elidjen, E., \& Sasmoko, S. (2018). Digital Transformation in the Age of Industry 4 . 0 : Acceleration of Transformational Performance through Business Model Innovation and Co-Creation Strategy in Indonesian ICT Firms Transformación digital en la era de la industria 4 . 0: Aceleración del. Opcion, 86(86), 2145-2159.

29. Nenonen, S., \& Storbacka, K. (2010). Business model design: conceptualizing networked value co-creation. International Journal of Quality and Service Sciences, 2(1), 43-59. https://doi.org/10.1108/17566691011026595

30. Onday, O. (2019). Japan's Society 5.0: Going Beyond Industry 4.0. Business and Economics Journal, 10(2), 1-6. https://doi.org/10.1001/jama.1958.02990280024007

31. Osterwalder, A., \& Pigneur, Y. (2010). Business Model Generation. John Wiley \& Sons, Inc., Hoboken, New Jersey (Vol. 1). https://doi.org/10.1523/JNEUROSCI.0307-10.2010

32. Özdemir, V., \& Hekim, N. (2018). Birth of Industry 5.0: Making Sense of Big Data with Artificial Intelligence, "The Internet of Things" and Next-Generation Technology Policy. OMICS: A Journal of Integrative Biology, 22(1), 65-76. https://doi.org/10.1089/omi.2017.0194

33. Palmer, A. (2010). Customer experience management: A critical review of an emerging idea. Journal of Services Marketing, 24(3), 196-208. https://doi.org/10.1108/08876041011040604

34. Parise, S., Guinan, P. J., \& Kafka, R. (2016). Solving the crisis of immediacy: How digital technology can transform the customer experience. Business Horizons, 59(4), 411-420. https://doi.org/10.1016/j.bushor.2016.03.004

35. Paschek, D., Mocan, A., \& Draghici, A. (2019). Industry 5 . 0 - The Expected Impact of Next Industrial Revolution. In managment knowledge learning international conference (pp. 125-132).

36. Priyanka Shrivastava. (2016). Effect of Co-Creation on Customer Experience, Trust and Brand Loyalty. International Journal of Sales \& Marketing Management Research and Development (IJSMMRD), 6(6), 1-14. Retrieved from http://www.tjprc.org/view-archives.php

37. Ramaswamy, V. (2008). Co-creating value through customers' experiences: The Nike case. Strategy and Leadership, 36(5), 9-14 https://doi.org/10.1108/10878570810902068

38. Ramaswamy, V. (2011). It's about human experiences...and beyond, to co-creation. Industrial Marketing Management, 40(2), 195-196. https://doi.org/10.1016/j.indmarman.2010.06.030

39. Seppanen, M., \& Laukkanen, I. (2015). Business model innovation: Focus on customer experience. In 2015 IEEE International Conference on Engineering, Technology and Innovation/International Technology Management Conference, ICE/ITMC (pp. 1-9) https://doi.org/10.1109/ICE.2015.7438657

40. Situmorang, S. H., Rini, E. S., \& Muda, I. (2017). Customer Experience, Net Emotional Value and Net Promoter Score on muslim middle class women in Medan. International Journal of Economic Research, 14(20), 269-283.

41. Sjödin, C., \& Kristensson, P. (2012). Customers' experiences of co-creation during service innovation. International Journal of Quality and Service Sciences, 4(2), 189-204. https://doi.org/10.1108/17566691211232918 
42. Stuart, F. I., \& Tax, S. (2004). Toward an integrative approach to designing service experiences Lessons learned from the theatre. Journal of Operations Management, 22(6), 609-627. https://doi.org/10.1016/j.jom.2004.07.002

43. Teece, D. J., \& Linden, G. (2017). Business models, value capture, and the digital enterprise. https://doi.org/10.1186/s41469-017-0018-x

44. Vokurka, R. J., \& Fliedner, G. (1998). The journey toward agility. Industrial Management and Data Systems, 98(4), 165-171. https://doi.org/10.1108/02635579810219336

45. Wang, F. Y., Yuan, Y., Wang, X., \& Qin, R. (2018). Societies 5.0: A New Paradigm for Computational Social Systems Research. IEEE Transactions on Computational Social Systems, 5(1), 2-8. https://doi.org/10.1109/TCSS.2018.2797598

46. Zhang, Y., Wen, J., Qiuli, Q. I. N., Hao, Y. U., Leminen, S., Rajahonka, M., ... Chan, H. C. Y. (2015). How Smart, Connected Products Are Transforming Companies. Blog.Prossess.Com, 4(4), 5-14. https://doi.org/10.1007/978-3-642-19157-2

47. Zott, C., \& Amit, R. (2010). Business model design: An activity system perspective. Long Range Planning, 43(2-3), 216-226. https://doi.org/10.1016/j.lrp.2009.07.004

48. Zott, C., \& Amit, R. (2017). Business Model Innovation: How to Create Value in a Digital World. Gfk Marketing Intelligence Review, 9(1), 18-23. https://doi.org/10.1515/gfkmir-2017-0003

\section{AUTHORS PROFILE}

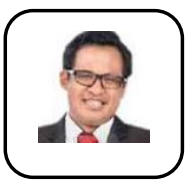

First Author Leonardus W Wasono Mihardjo is a Doctor candidate in Management at Bina Nusantara University, West Jakarta, Indonesia. His research has attracted funding award from Indonesia Ministry of research and higher education in 2019, as well as awarded as best paper in Malaysian conference 2018. Currently, he is a director of Financial and Business Partner at PT Telekomunikasi Indonesia International (Telin) focus on financial and development of Human capital. He is also chairman of PT Telin Australia and Board member of Telin Singapore. He has more than 20 years in Telecommunication Industry with 12 years in Telkomsel. His research interest includes digital transformation, business model innovation, technology, digital leadership and strategic management Orcid ID ; orcid.org/0000-0002-3820-4960

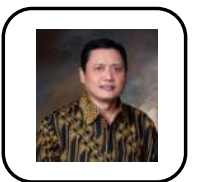

\section{Second Author Sasmoko}

Sasmoko is a Professor of Research Methods of Faculty of Humanities at Bina Nusantara University, Jakarta. He is currently working at the RIG-Education Technology, Binus University. Their most recent publication is 'Applying indonesian teacher engagement index (ITEI) apps: Self-diagnostic apps for teachers in Indonesia', including the use of Artificial Intelligent for education and social Science. His researches have attracted funding award from Indonesia Ministry of research and higher education and also from Bina Nusantara university.

His research interest includes teaching methods, teacher education and educational assessment, including the use of Technology for Education Orcid ID: orcid.org/0000-0001-9219-9237

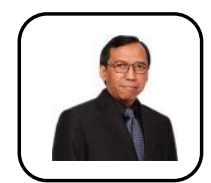

Third Author Firdaus Alamsjah is currently the Executive Dean and Provost of the Bina Nusantara Business School, where he also serves as a faculty member. He is a managing partner at Binus Consulting and Training. He has more than 20 years of extensive experience is in consulting, training, and teaching, which complements his research interests in strategy execution, supply-chain management and business process management, digital technology and social science. He earned his PhD in Industrial Engineering and his MSIE from the University of Houston, USA. His bachelor's degree in mechanical engineering was completed at ITB Bandung

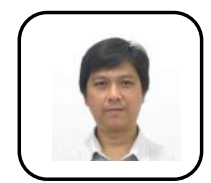

Fourth Author Elidjen is an Associate Professor of Computer Science at Bina Nusantara University. He obtained his Doctoral in Management from Bina Nusantara University. $\mathrm{He}$ has research background in computer science and more than 20 years extensive experience in Teaching and research. He has appointed as head of Binus corporation management focus on development knowledge management and innovation, including the use of artificial intelligent for social science. His research interest includes knowledge management, organization learning innovation, computer engineering and software engineering. $\mathrm{He}$ was graduated $\mathrm{PhD}$ in Strategic growth from Bina Nusantara University, and M. InfoCommTech from University of Wollongong, New South Wales, Australia. 